\title{
Determinants of current account imbalance in the global economy: a dynamic panel analysis
}

\author{
Debasish Kumar Das ${ }^{*}$
}

*Correspondence:

dkdas.econ@gmail.com

Economics Discipline, Khulna

University, Khulna 9208,

Bangladesh

\begin{abstract}
This paper presents an empirical investigation of the determinants of current account imbalance for the large sample of developed, emerging and developing countries during 1980-2011. Using dynamic panel GMM techniques, this study characterizes that current account balance is positively correlated with net foreign assets, trade openness and exchange rate stability and negatively associated with commodity price, real GDP growth and real effective exchange rate for the developed countries. While, among emerging countries, commodity price, real GDP growth, trade openness and de jure capital openness are positively correlated with net foreign asset, exchange rate stability index is negatively related to current account balance. These findings suggest that the current account determinants explain different characteristics in terms of different country groups.
\end{abstract}

Keywords: Current account determinants, Global imbalance, Dynamic panel GMM

JEL Classification: F62, F30, C33

\section{Background}

Today the world aggregate current account balances as a share of global output are twice as large as in mid-1980s, while the net foreign asset positions have boosted up threefold (Bracke et al. 2010). Global current account imbalance is also rising with the USA and other major developed economies running a persistent current account deficit against some emerging market countries with big surpluses. Notably, the 2007 US current account deficit has enlarged to $6 \%$ from $2.4 \%$ in 1998. Alike, the Eurozone current account deficit has widened over $4 \%$ of GDP in 2008. This unexpected rise in current account deficit beyond historical standard has received a substantial attention in recent year.

On contrary, China and other Asian Tigers (South Korea, Malaysia, Singapore, Indonesia and Thailand) are running current account surplus on an average $6.4 \%$ of GDP in 2000-2009 which put forward them to one of the world's largest lender. In spite of having rapid growth and enormous domestic investment opportunities, these economies have increasingly been outflowing a major portion of their savings to foreign countries. Additionally, other emerging economies including Mexico, Argentina, Brazil and Middle

(c) 2016 Das. This article is distributed under the terms of the Creative Commons Attribution 4.0 International License (http:// creativecommons.org/licenses/by/4.0/), which permits unrestricted use, distribution, and reproduction in any medium, provided you give appropriate credit to the original author(s) and the source, provide a link to the Creative Commons license, and indicate if changes were made. 
Eastern oil exporters also are increasing their potentiality toward current account surpluses since 1990s. Thus, many (Bernanke 2005; Prasad et al. 2007; Carroll and Jeanne 2009; Buera and Shin 2009; Aguiar and Amador 2011; Miller et al. 2011) observe that superfluous savings is uphilling from capital-scarce emerging and developing economies to the capital-abundant developed countries during the last two decades. This observed counterintuitive phenomenon widely revealed as 'Lucas Paradox.'

Many alternative theoretical models (Bussière et al. 2004; Obstfeld and Rogoff 1995b; Caballero et al. 2008; Edwards 1996; Gourinchas and Jeanne 2013) have given diverse forecast of the underlying determinants of current account imbalances. Some empirical studies (Debelle and Faruqee 1996; Chinn and Prasad 2003; Chinn and Ito 2007; Lee et al. 2008) have tested these theoretical framework, either directly or indirectly to examine the determinants of current account balance. Since, most of the studies consider only developed and some emerging economies, which limit to capture the actual impact of potential current account determinants. Given this background, it is essential to find out the significant determinants using advanced technique and large sample which is rarely portrayed either in theory or in empirical investigation. Thus, the determinants of global current account imbalance remain ambiguous in theoretical and empirical discussion. Hence, this research contributes a broad empirical characterization to analyze the determinants of global current account imbalances covering a large heterogeneous group of 106 countries under dynamic panel GMM framework.

The main reference comes from few empirical papers (Glick and Rogoff 1995; Calderon et al. 2002; Chinn and Prasad 2003; Gruber and Kamin 2007; Chinn and Ito 2007) on the determinants of current account balance from which this article borrow the baseline information. Except others' this study improves this work in two way, first, use commodity price index, de jure classification of capital openness and exchange rate stability index along with other commonly used determinants (e.g., net foreign assets, real effective exchange rate, real GDP growth and trade openness), which better captures the determinants of global current account imbalances. Second, employ the difference and system GMM estimation in a strongly balanced panel framework of 106 sample countries (among them 27 developed, 32 emerging and 47 developing economies) using enriched data from various sources over the time period 1980-2011.

It is essential to emphasize at this point that this paper does not intent to revisit the previous finding in the current or capital account literatures. Instead, it draws on those finding only to obtain a reasonable set of additional explanatory and control variables along with commonly used determinants in the literature to find the determinants of global current account imbalances.

This paper proceeds as follows. Section 2 lays out the empirical motivation. Section 3 contains a discussion of some theoretical and empirical literature. Section 4 describes data and descriptive statistics. Section 5 presents estimation techniques. Section 6 describes the results, while Sect. 7 details the results of selected robustness checks. Finally, Sect. 8 offers conclusion and direction for future research.

${ }^{1}$ Lucas (1990) stressed the failure of standard neoclassical growth models to explain the movement of international capital flows. In fact, neoclassical models forecast capital flows from rich to poor countries while Lucas Paradox accounts for the dynamics of current account imbalances and uphill capital flows. 


\section{Empirical motivation}

The first fact that motivates this analysis is the observation of global current account imbalance as emerging economies run current account surplus while developed economies widen their deficits. Figure 1 shows the global current account balance as percentage of $\mathrm{GDP}^{2}$ considering different countries and groups, i.e., Eurozone, BRICS and Asian tigers. It observes that USA and Eurozone economies (excluding Germany) have run large and persistent current account deficit from 2000s and China and other emerging economies are running high and persistent current account surpluses.

Thus, it can be plausible that this disorder current account imbalance is carrying risk. As a result, the uphill capital flows funding for current account deficit could be a big change in exchange rate with possibly global ramifications. Additionally, there is always a potential risk of huge trade imbalances that might force deficit economies twist to protectionist measures.

Accordingly, to analyze the determinants of global current account imbalance, it is vital to check whether the trend of current account balance is persistent or not. While dealing with dynamism, if the current account is not persistent, the validity of the estimated result will be debatable. Although the implication of the current account has undergone through several tests, it is very difficult to draw a generalized conclusion about its sustainability because of the inconsistency in the literature (Clower and Ito 2011). Some studies reveal that some economies may hold unsustainable current account balance for the short term (Raybaudi et al. 2004; Taylor 2002). Hence, the key attentions search through the persistency of current account balance prior to examine its determinants.

The second key observation induces to the financial openness in perspectives of both de jure and de facto measures by considering Chinn and Ito (2008) index of the degree of capital openness as a de jure measure. This index value is based on information regarding restrictions in the IMF's Annual Report on Exchange Arrangements and Exchange Restrictions (AREAER), which is normalized between 0 and 1 . Higher values of this index indicate that a country is more open to cross-border capital transactions.

As de jure capital openness depicts how flexible the countries' law is, thus to get complete picturization, this paper also measured de facto capital openness which indicates the sum of total foreign assets and total foreign liabilities over GDP multiplied by 100 . The de facto capital openness shows that how much the country is really open for the financial and macroeconomic integration.

Figure 2 exhibits the de jure capital openness (in left axis) for the group of developed, emerging and developing economies. This index captures that developed economies have been more opened gradually last three decades, following emerging and developing economies have also been started to more open after 1990s but not as fast as developed economies are. While in de facto measures reflects that developed economies started closely as open as in de jure measure in 2000s; whereas emerging and developing economies are not reflects practically as much as their de jure measures are, because of most of the developing and emerging economies circumscribed with underdeveloped domestic financial markets.

${ }^{2}$ GDP measures in current US \$. 

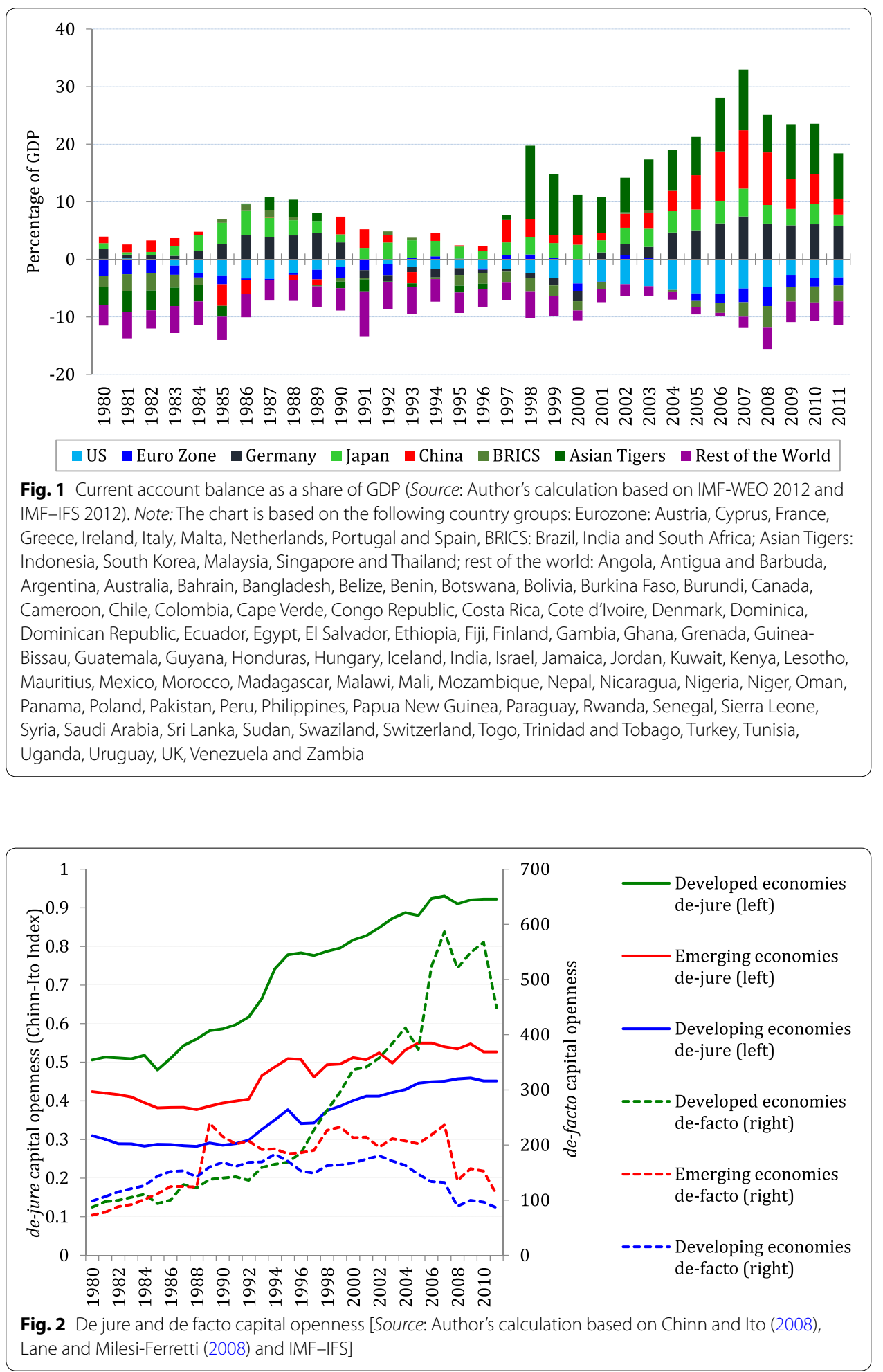

The third fact emerges from the issue of manufacture exporting developed countries and commodity exporting emerging and developing countries. The large volume of export from emerging and developing countries is increasing their aggregate savings and 
national income. Along with their cautious financial policy against Western exuberance in consumption and residential investment, massive export earnings help to boost up the current account surplus (Miller et al. 2011). Therefore, the commodity price might have an influence in balancing the current account imbalance. Hence, this paper constitutes commodity price index by using an interaction dummy variable which is the multiplication of price indices of prime export items and commodity export dummy. In Fig. 3, the commodity price index exhibits an upward trend after 2000s with an elevated pace of economic globalization. Although the trend got some sudden shock after global financial crisis in 2007-2008, the price trend restored its peak position in 2010 again. Seemingly, the commodity price index trend assists the emerging and developing countries to hold a standard surplus whose current account transactions are mainly dependent on commodity exports.

Finally, taking into account the exchange rate stability as one of the key determinant of current account imbalance. The index value calculates yearly standard deviation of monthly exchange rate between home and base country to measure exchange rate stability index (Aizenman et al. 2010). The USA is considered as the base country for emerging and developing economies, and Germany is treated as base for EU countries. The index value is normalized between 0 and 1 by using the prescribed formula. ${ }^{3}$ The lower bound of the exchange rate stability index (0) indicates the instability, and the upper bound (0) indicates exchange rate stability.

\section{Literature review}

The beginning of the global current account imbalance analysis dates back to Sachs (1981) through the intertemporal approach and follows up by Obstfeld and Rogoff (1984), Milesi-Ferrett and Razin (1996) and Milesi-Ferretti and Razin (1998a, b). The standard approach to this hypothesis focuses on the issue that current consumption is equal to the share of the present discounted value of future expected net output or net assets. Therefore, the change in current consumption is determined by either change in interest rate or future expectation of assets due to productivity shocks or reduced investment and government expenditure (Chinn et al. 2014). This model provides diversified channels of positive and negative income shocks, productivity shocks and liquidity constraint for explaining current account determination (Obstfeld and Rogoff 1995b). Several empirical studies (Sheffrin and Woo 1990; Milbourne and Otto 1992; Otto and Voss 1995; Bergin 2006) have been focused on intertemporal approaches of global current account imbalances. They mainly observed the additional determinants that possibly will affect consumption and savings decision.

However, the origin of current account imbalance has been theoretically explicated in two basic views. The first view deems imbalance as an oscillating trend, which is better termed as 'disequilibrium approach.' The second view characterizes a completely reverse outlook that current account imbalance is an equilibrium situation in which the change in determinants can be self-sustaining, which is better termed as 'equilibrium approach. Under the disequilibrium approach, Obstfeld and Rogoff $(2005,2009)$ emphasize the magnitude of depreciation and trade balance correction for the current imbalance. Some studies

${ }^{3} \mathrm{ERS}=1 /\left[1+\left\{\operatorname{stdev}(\right.\right.$ exch_rate $\left.\left.) / d \log E_{t} / \mathrm{d} t+0.01\right\}\right]$. 


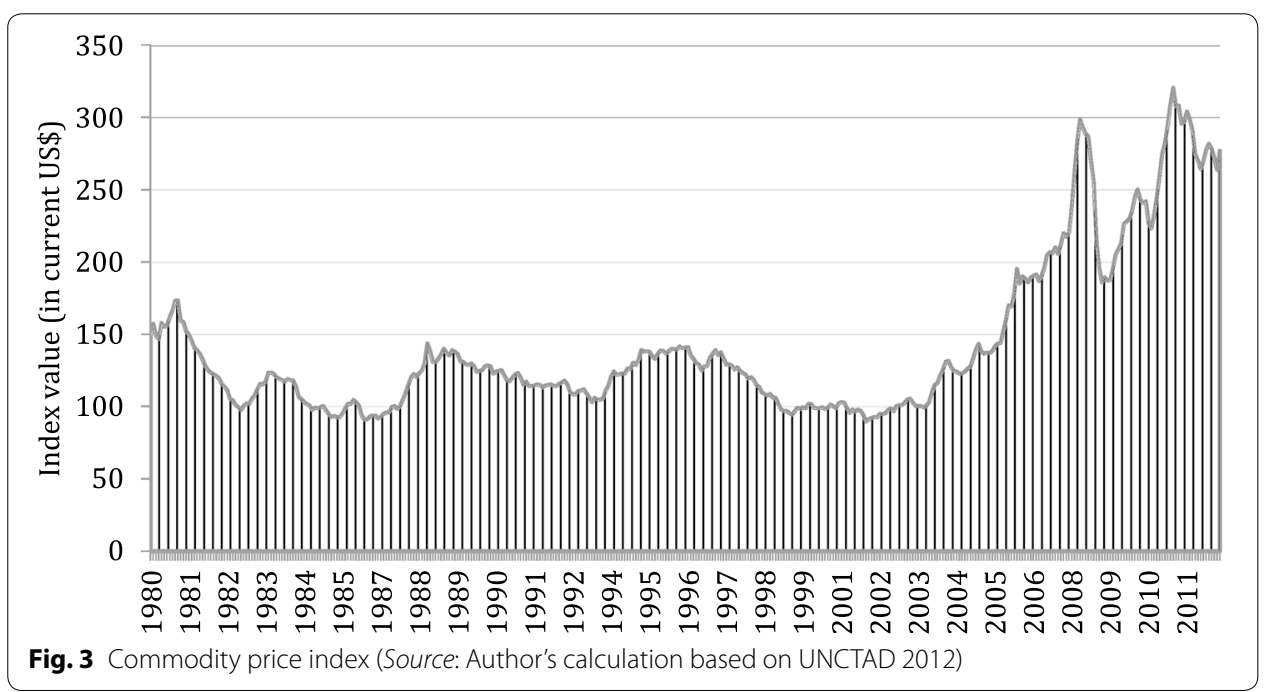

(Gourinchas and Rey 2007; Blanchard et al. 2005) dictate that real adjustment and financial adjustment are necessary for global financial or balance sheet correction because of the change in countries' net foreign asset positions. Since, net foreign asset position consists of the change in the price of foreign asset and liabilities and the current account balance.

As opposed to the disequilibrium approach, which emphasizes the current account, equilibrium approach highlights the capital account. On the issue of international asymmetries in the supply and demand of financial assets, Caballero et al. (2008) emphasize that the financial underdevelopment of the emerging economies causes less attractive financial tools for the savers due to instable and volatile financial market. This financial underdevelopment and financial crisis including Mexico in 1994, East Asian countries in 1997, Brazil in 1999, Argentina in 2002 and Turkey in 2003 creates flow of US deficit, which is usually known as 'global saving glut' hypothesis (Bernanke 2005; Clarida 2005). Miller et al. (2011) discern, after the financial crisis in the emerging countries, they adopted cautious financial policy, whereas exuberance in consumption, housing and credit of the Western countries crafted the global imbalance severe.

Moreover, for investigating the ground of saving glut hypothesis, one should assess the financial and institutional development explaining the pattern of global current account imbalance. Using a structural model (Chinn and Ito 2007) makes opposite stand to the lower savings rate after achieving the infrastructural and financial development in emerging market particularly in East Asia. Similarly, Miller et al. (2011) find the massive saving in Asian emerging nations has hardly been a causal factor for the current account imbalance. For the explanation and forecasting of the current account imbalance, the results are very sensitive to the different indicators of financial development such as bond, equity, insurance market activity, cost, size and activeness of the industry (Ito and Chinn 2007). Additionally, on the ground of the stakeholder's behavior, irrational optimistic or pessimistic vision (Akerlof and Shiller 2010), market imperfections because of asymmetries in information (Stiglitz 2010) and rent seeking (Johnson and Kwak 2011) cause financial distortion and pave the way to global current account imbalance. 
A dearth number of researchers have highlighted the capital flows to emerging and developing countries underlying the 'push' and 'pull' factors (Calvo et al. 1993; Corbo and Hernandez 1996; Fernandez-Arias and Montiel 1996). While dealing with capital flow, one may need to consider current and capital account reversal. A large deficit indicating temporary flow of investment with high productivity growth and profitability will have a different implication that the temporary deficit with high public consumption and currency overvaluation. Milesi-Ferretti and Razin (2000) analyze the indicators that could forecast current account reversal and suggested to reduce current account deficit at least 3-5 \% of GDP over the time of 3 years. De Mello et al. $(2011,2012)$ claim that current account reversal has a long-term impact on the economic growth, whereas other policy analyst (Abiad et al. 2009; Freund and Warnock 2007; Debelle and Galati 2007) treated it as short-lived phenomenon.

Chinn and Prasad (2003) emphasize that instead of capital controls country's financial development is positively correlated with current account balance in developing countries. Contradicting this result, Cheung et al. (2013) and Mendoza et al. (2009) show that financial sector development measured by private credit ratio has a negative impact on current account balance. Such negative relation might arise from the fact that developed financial system and legal investment protection regulation may divert the capital flows into other countries with more liquid assets and competitive market (Bernanke 2005; Ju and Wei 2006). Similarly, Alfaro et al. (2008) confirm that domestic and international market imperfection, low institutional quality and weak governance structure in developing countries increase the investor's high risk of return. Thus, capital is uphilling in the relatively more stable and developed financial system particularly in European and North American economies (Caballero et al. 2008). Besides, based on an empirical research of a panel of developing countries Calderon et al. (2002) reveal that high current account deficit tends to associate with output growth, in terms of trade shock and currency appreciation. However, past global economic shocks such as Asian crisis, Latin American crisis and recent financial crisis reduce the investment levels (Reinhart and Rogoff 2008; Chinn and Ito 2007; Eichengreen 2006).

Summing up the above literature survey, it is obvious that various theory and empirical results produce heterogeneous predictions on the underlying determinants of current account imbalance which opens the avenue for further investigation. However, in the literature some important variables such as commodity price and exchange rate stability are largely ignored as a determinant. Thus, the main objective of this research is to investigate considering these variables together with other important determinants supported by the literature (Glick and Rogoff 1995; Chinn and Prasad 2003; Chinn and Ito 2007) employing advanced estimation techniques across different groups of countries.

\section{Data and descriptive statistics}

This paper considers a strongly balanced panel of annual data for 106 countries over the period 1980-2011. The basic dataset has annual data for 27 high-income industrial, 32 emerging and 47 developing countries around the world. The sample country groups are selected according to the IMF World Economic Outlook, World Bank, S\&P and FTSE. ${ }^{4}$

${ }^{4}$ S\&P indicates Standard \& Poor's Financial Services; FTSE indicates Financial Times Stock Exchange Group. 
Variable definitions and data sources as well as list of countries in same and country grouping are presented in "Appendix." This constructed dataset considers eight potential current account imbalance determinants for the analysis. It assumes that a subset of the fundamental along with the main variables is relevant and let the estimation techniques to determine which are the most important determinants in the global economy.

This research uses data from various sources, including IMF Balance of Payment Statistics (BOPS), World Bank Development Indicators (WDI), United Nations Conference for Trade and Development (UNCTAD), IMF International Financial Statistics (IFS), Bank of International Settlements (BIS), Lane and Milesi-Ferretti (2008), Chinn and Ito (2012), PWT (2012), Laeven and Valencia (2012), Aizenman et al. (2012) and Darvas (2012).

For this panel dataset, it considers current account balance (is the sum of net exports of goods, services, net income and net current transfers) as a share of gross domestic product (GDP) as an dependent variable and the explanatory determinants are lagged dependent variable, real GDP growth rate, real effective exchange rate, commodity price index, net foreign assets as a share of GDP, trade openness, de jure capital openness index and exchange rate stability index. Table 1 represents the summary statistics of the concerned variables.

\section{Estimation techniques}

In this section, firstly, employ the panel unit root test to reveal that whether a cointegration relationship is present in the current account balance for all countries during the sample period. Secondly, estimate the dynamic generalized method of moments (GMM) panel estimators.

\subsection{Panel unit root test}

This work starts with panel unit root test for corresponding variables. Panel unit root test is developed from time-series unit root test. This development emphasized to combine the asymptotic characteristics of the time-series dimension $T$ and cross-sectional dimension $N$. There are several procedures to analyze the panel unit root tests. Among them, I use Levin-Lin-Chu test (LLC) and Im-Pesaran-Shin test (IPS) test.

Table 1 Summary statistics

\begin{tabular}{|c|c|c|c|c|c|c|}
\hline \multirow[t]{2}{*}{ Variable description } & \multicolumn{2}{|c|}{$\begin{array}{l}\text { Developed ( } 27 \text { coun- } \\
\text { tries, } 864 \text { annual obs.) }\end{array}$} & \multicolumn{2}{|c|}{$\begin{array}{l}\text { Emerging ( } 32 \text { coun- } \\
\text { tries, } 1024 \text { annual } \\
\text { obs.) }\end{array}$} & \multicolumn{2}{|c|}{$\begin{array}{l}\text { Developing (47 } \\
\text { countries, } 1504 \\
\text { annual obs.) }\end{array}$} \\
\hline & Mean & Std. dev. & Mean & Std. dev. & Mean & Std. dev. \\
\hline Current account balance (\% of GDP) & -0.63 & 5.67 & -0.39 & 12.49 & 13.27 & 21.03 \\
\hline Real GDP growth rate & 2.60 & 2.84 & 4.40 & 5.34 & 3.32 & 4.92 \\
\hline$\Delta$ Real effective exchange rate & 0.34 & 6.89 & 0.06 & 13.17 & 0.68 & 25.71 \\
\hline Commodity price index & 40.54 & 72.89 & 128.7 & 76.29 & 135.8 & 71.61 \\
\hline Net foreign assets (\% of GDP) & -21.56 & 41.65 & -16.34 & 74.31 & -78.84 & 85.63 \\
\hline Trade openness & 52.28 & 22.58 & 63.20 & 54.97 & 58.36 & 31.89 \\
\hline de jure capital openness & 0.73 & 0.32 & 0.46 & 0.33 & 0.36 & 0.29 \\
\hline Exchange rate stability index & 0.51 & 0.28 & 0.55 & 0.31 & 0.70 & 0.34 \\
\hline
\end{tabular}




\subsubsection{Levin-Lin-Chu (LLC) test}

One of the first panel unit root tests formulated by Levin et al. (2002) suggests the following hypotheses for testing stationarity in panel data. Under null hypothesis, LLC test shows that each time series contains a unit root, i.e., $H_{0}: \rho_{i}=0 \forall i$, and for alternative hypothesis, each time series is stationary, i.e., $H_{A}: \rho_{i}=\rho<0 \forall i$. Like other unit root tests in the literature, LLC assume that the individual processes in each cross section are independent. The LLC test is mainly based on the estimation of the following equation.

$$
\Delta y_{i, t}=\alpha_{i}+\delta_{i} t+\theta_{t}+\rho_{i} y_{i, t-1}+\varsigma_{i, t} \quad \text { where } \quad \mathrm{i}=1,2, \ldots, N \quad t=1,2, \ldots, T
$$

This test might be treated as a pooled Dickey-Fuller or augmented Dickey-Fuller test potentially with different time lags across the units of the panel.

\subsubsection{Im-Pesaran-Shin (IPS) test}

The IPS test formulated by Im et al. (2003) is the extension of LLC test incorporating heterogeneity in the dataset under alternative hypothesis. Here, IPS test estimation is also based on Eq. (1). The null hypothesis is stated as $H_{0}: \rho_{i}=0 \forall i$ against the alternative hypothesis of $H_{A}: \rho_{i}<0$ where $i=1,2,3, \ldots, N_{1} ; \rho_{i}=0, i=N_{1}+1, N_{1}+2, \ldots, N$. In IPS test, it is presumed that all series is non-stationary under null hypothesis and a fraction of the series is stationary under alternative hypothesis. It is the difference with LLC test, in which all series are supposed to be stationary under alternative hypothesis.

\subsection{GMM estimators for dynamic panel models}

This section specified the dynamic panel GMM estimators that were pioneered by Holtz-Eakin et al. (1988), Arellano and Bond (1991), Arellano and Bover (1995), Blundell and Bond (1998) and Bond et al. (2001). The panel consists of data from 106 countries over the time period 1980-2011. Since this research uses yearly data, the panel permits 32 observations for each country. In dynamic framework, equation can be written in following specifications:

$$
\mathrm{CAB}_{i, t}=\alpha+\gamma_{1} \mathrm{CAB}_{i, t-1}+\beta^{\prime}[X]_{i, t}+\eta_{i}+\varepsilon_{i, t}
$$

where $\mathrm{CAB}$ is the current account balance treated as a dependent variable and $X$ represents the set of explanatory variables (real GDP growth rate, $\Delta$ real effective exchange rate, commodity price index, net foreign assets, trade openness, de jure capital openness (Chinn-Ito index), de facto capital openness, exchange rate stability index and crisis dummy) other than the lagged current account balance. $\varepsilon_{i, t}$ is an independently distributed error term with $E\left[\varepsilon_{i, t}\right]=0$, and the subscripts $I$ and $t$ denote country and time period, respectively. $\eta_{i}$ is an unobserved country-specific effect which is not correlated with $\varepsilon_{i, t}$, and $i=1, \ldots, N$ and $t=2, \ldots, T$, where $\left(\eta_{i}+\varepsilon_{i, t}\right)$ have the standard error component structure; For Eq. (2), $E\left[\eta_{i}\right]=0, E\left[\varepsilon_{i, t}\right]=0, E\left[\varepsilon_{i, t}, \eta_{i}\right]=0$ for $i=1, \ldots, N$ and $t=2, \ldots, T$

Now, take the first difference to eliminate country-specific effects of Eq. (3),

$$
\mathrm{CAB}_{i, t}-\mathrm{CAB}_{i, t-1}=\alpha+\gamma_{1}\left(\mathrm{CAB}_{i, t-1}-\mathrm{CAB}_{i, t-2}\right)+\beta^{\prime}\left[X_{i, t}-X_{i, t-1}\right]+\left(\varepsilon_{i, t}-\varepsilon_{i, t-1}\right)
$$


In Eq. (3), the lagged dependent variable $\mathrm{CAB}_{i, t}-\mathrm{CAB}_{i, t-1}$ is correlated with error term $\left(\varepsilon_{i, t}-\varepsilon_{i, t-1}\right)$, which implies that the regressors are likely endogenous. Thus, need to use instruments to deal with Eq. (3). According to econometric assumptions, the error term is not serially correlated and the regressors are weakly exogenous. ${ }^{5}$ Therefore, the dynamic panel GMM estimator employs the following moment conditions based on difference estimator for Eq. (2);

$$
\begin{aligned}
& E\left[\mathrm{CAB}_{i, t-s}\left(\varepsilon_{i, t}-\varepsilon_{i, t-1}\right)\right]=0 \text { for } t=3, \ldots, T, \quad s \geq 2 \\
& E\left[X_{i, t-s}\left(\varepsilon_{i, t}-\varepsilon_{i, t-1}\right)\right]=0 \quad \text { for } t=3, \ldots, T, \quad s \geq 2,
\end{aligned}
$$

which can be written in following matrix form as:

$$
M=\left(\begin{array}{ccccccc}
y_{i 1} & 0 & 0 & \cdots & 0 & \cdots & 0 \\
0 & y_{i 1} & y_{i 2} & \cdots & 0 & \cdots & 0 \\
\vdots & \vdots & \vdots & \vdots & \vdots & \vdots & \vdots \\
0 & 0 & 0 & \cdots & y_{i 1} & \cdots & y_{i, T-2}
\end{array}\right)
$$

Here, $M$ is the instruments matrix corresponding to the endogenous variables, where $y_{i, t-s}$ refers to $\mathrm{CAB}_{i, t-s}$ for Eq. (4).

However, the first difference estimator is criticized in terms of bias and imprecision. Thus, to reduce potential biases and imprecision, Blundell and Bond (1998) suggest that, when regressors have short time period, we can use a new estimator that combines a system in the difference estimator with the estimator in levels, which is called the Blundell and Bond system GMM. The difference operator in Eq. (4) uses the same instrument as above, and the instruments for the levels are the lagged difference of the regressors. The econometric assumption here is that the difference in the regressors and the country-specific effect are uncorrelated. Therefore, the stationary properties are:

$$
E\left[\mathrm{CAB}_{i, t+p} \eta_{i}\right]=E\left[\mathrm{CAB}_{i, t+q} \eta_{i}\right] \text { and } E\left[X_{i, t+p} \eta_{i}\right]=E\left[X_{i, t+q} \eta_{i}\right] \quad \forall p \text { and } q
$$

The additional moment conditions for the levels are

$$
\begin{aligned}
& E\left[\Delta \mathrm{CAB}_{i, t-s}\left(\eta_{i}+\varepsilon_{i, t}\right)\right]=0 \quad \text { for } \quad s=1 \\
& E\left[\Delta X_{i, t-s}\left(\eta_{i}+\varepsilon_{i, t}\right)\right]=0 \quad \text { for } \quad s=1
\end{aligned}
$$

Now, use system GMM technique for both models to estimate consistent and efficient parameter by employing the moment conditions given in Eqs. (4), (5), (6) and (7). To get more robustness of the result, this paper also instrumented the net foreign assets and exchange rate stability index and de facto capital openness to overcome the potential endogeneity which generates more consistent and efficient parameters.

To check the validity of the instruments in the system GMM estimator, this research implemented several specification tests, which is suggested by Arellano and Bond (1991), Arellano and Bover (1995) and Blundell and Bond (1998): first, the Sargan and Hansen J tests for over-identification to check the validity of the instruments; second, the Diff-inHansen test to check the validity of additional moment restriction necessary for system

\footnotetext{
${ }^{5}$ Assuming that the regressors are not correlated with future error terms.
} 
GMM; and finally, Arellano-Bond test to check the hypothesis that error term is serially uncorrelated.

\section{Results}

This section presents the estimation results, which aims to find the determinants of current account imbalances in the global economy. Firstly, check the stationarity of the panel dataset by using Levin-Lin-Chu (LLC) and Im-Pesaran-Shin (IPS) unit root tests. Secondly, estimate Eq. (2) on the dataset described above by using difference and system GMM panel estimation. Subsequently, Sargan and Arellano-Bond (AB) tests to check the validity of the model and finally verify the robustness.

\subsection{Panel unit root test results}

The analysis begins with the panel unit root test using LLC and IPS tests. Table 2 reports the panel unit root test estimates for the potential determinants of current account imbalances in the sample of 106 countries. The test specification exhibits that in all series the null hypothesis is rejected. This implies that there is no cointegrated relationship because the current account balance is stationary series in panel countries during the sample period.

\subsection{Basic results: persistency}

Table 3 shows the result of the different estimators for simple AR (4) regression of the current account balance to observe its persistency. As various theoretical frameworks confirm that if the dynamics of current account generate persistent stochastic shocks to the economy, they remain stationary around steady state which affects optimal intertemporal income-savings decision (Glick and Rogoff 1995; Obstfeld and Rogoff 1995b; Trehan and Walsh 1991; Aizenman 2006). Considering this theoretical standpoint, various estimation techniques (presented in Sect. 5) show (in Table 3) the coefficients of the lagged dependent variables are persistent as expected and described in Sect. 2.

The estimators of the 1-year lagged current account balance add to 0.535 and 0.157 , $0.134,0.126$ of 2,3 and 4 years lagged, respectively, for the pooled OLS model in specification (1), 0.434, 0.065, 0.053 and 0.047 in the within-group (fixed effects) estimator of specification (2), 0.382, 0.039, 0.032 and 0.027 in the difference GMM estimation in specification (3) and $0.378,0.024,0.038$ and 0.024 in the system GMM model in specification (4), respectively. The AR (4) result indicates that the previous four terms and the noise term contribute to the current account balance. All four lags are positive, meaning that there is a persistent effect of the dynamics of current account balance. For more robustness check, this research considered AR (4) process instead of AR (1) or AR (2)

Table 2 Panel unit root test

\begin{tabular}{llllll}
\hline Variables & CAB & Real GDP \\
& (\% of GDP) & growth rate & REER & $\begin{array}{l}\text { NFA } \\
\text { (\% of GDP) }\end{array}$ & $\begin{array}{l}\text { Openness } \\
\text { of trade }\end{array}$ \\
\hline Levin-Lin-Chu (LLC) & $-11.06^{* * *}$ & $-30.62^{* * *}$ & $-32.64^{* * *}$ & $-5.19^{* * *}$ & $-10.50^{* * *}$ \\
Im-Pesaran-Shin (IPS) & $-8.61^{* * *}$ & $-31.09^{* * *}$ & $-32.43^{* * *}$ & $-3.19^{* *}$ & $-7.15^{* * *}$ \\
\hline
\end{tabular}

Panel unit root is not tested for commodity price index, de jure capital openness and exchange rate stability index. These variables are containing either index or dummy ( 0 and 1$)$ value, which is irrelevant for the test in this respect 
Table 3 Persistency results [AR(4) process of current account balance]

\begin{tabular}{lllll}
\hline & $\begin{array}{l}\mathbf{( 1 )} \\
\text { POLS }\end{array}$ & $\begin{array}{l}(\mathbf{2}) \\
\text { FE }\end{array}$ & $\begin{array}{l}\text { (3) } \\
\text { DGMM }\end{array}$ & $\begin{array}{l}\text { (4) } \\
\text { SGMM }\end{array}$ \\
\hline Lag 1. CAB (\% of GDP) & $0.535^{* * *}$ & $0.434^{* * *}$ & $0.382^{* * *}$ & $0.378^{* * *}$ \\
& $(0.017)$ & $(0.018)$ & $(0.004)$ & $(0.005)$ \\
Lag 2. CAB (\% of GDP) & $0.157^{* * *}$ & $0.065^{* * *}$ & $0.039^{* * *}$ & $0.024^{* * *}$ \\
& $(0.017)$ & $(0.017)$ & $(0.002)$ & $(0.002)$ \\
Lag 3. CAB (\% of GDP) & $0.134^{* * *}$ & $0.053^{* * *}$ & $0.032^{* * *}$ & $0.038^{* * *}$ \\
& $(0.012)$ & $(0.012)$ & $(0.003)$ & $(0.004)$ \\
Lag 4. CAB (\% of GDP) & $0.126^{* * *}$ & $0.047^{* * *}$ & $0.027^{* * *}$ & $0.024^{* * *}$ \\
& $(0.014)$ & $(0.013)$ & $(0.003)$ & $(0.003)$ \\
Observations & 3180 & 3180 & 3074 & 3180 \\
R-squared & 0.42 & 0.47 & - & - \\
Number of country & 106 & 106 & 106 & 106 \\
\hline
\end{tabular}

Dependent variable is current account balance (\% of GDP) (CAB)

Standard errors in parentheses

(1) Pooled OLS, (2) fixed effects (within-group estimator), (3) difference GMM (Arellano and Bond 1991) and (4) system GMM (Blundell and Bond 1998)

*** Significant at $1 \%$; ** significant at $5 \%$; significant at $10 \%$

of the current account balance to observe its persistency. In addition, various panel unit root tests (in table 6.1) confirmed that the current account balance (as a share of GDP) is stationary.

\subsection{Dynamic panel GMM estimation results}

According to the econometric assumptions, it known that the pooled OLS estimation is upward biased and the fixed effects model is downward biased (Baltagi 2008). However, using Monte Carlo experiments Blundell and Bond $(1998,2000)$ and Blundell et al. (2002) demonstrate that the difference GMM estimators of the lagged dependent variable are strongly downward biased. Hence, they suggest for the system GMM estimation, which is set between the upper bound of pooled OLS estimation and lower bound of fixed and difference GMM estimation. Thus, this paper considers difference and system GMM techniques as an efficient estimators. Moreover, in each estimation, it checks the validity of the additional instruments and moment restrictions in the system GMM model compared with the difference GMM estimation. Tables 4 and 5 show the difference and system GMM estimation result of developed, emerging, developing and all countries specified in specification (1), (2), (3) and (4), respectively.

\subsubsection{Difference GMM estimation}

The dynamic panel difference GMM estimation result shows the effect of potential determinants on current account imbalance in specification (1)-(4). Table 4 presents the result using Arellano and Bond (1991) difference GMM estimators. These specifications consider current account balance (CAB) (\% of GDP) as a dependent variable with a lagged dependent variable and set of other explanatory variables (Eq. 2). The coefficients

of the lagged current account balance confirm the significance of including this variable 
Table 4 Difference dynamic panel estimation results (Arellano and Bond 1991 difference GMM approach)

\begin{tabular}{|c|c|c|c|c|}
\hline & $(1)$ & $(2)$ & (3) & (4) \\
\hline & Developed & Emerging & Developing & Full sample \\
\hline \multirow[t]{2}{*}{$\operatorname{Lag} C A B(\%$ of GDP) } & $0.752^{* * *}$ & $0.396^{* * *}$ & $0.602^{* * *}$ & $0.420^{* * *}$ \\
\hline & $(0.026)$ & $(0.006)$ & $(0.061)$ & $(0.0007)$ \\
\hline \multirow[t]{2}{*}{ Real GDP growth rate } & $-0.174^{* * *}$ & $0.627^{* * *}$ & $-0.049^{* * *}$ & $0.383^{* * *}$ \\
\hline & $(0.015)$ & $(0.049)$ & $(0.012)$ & $(0.002)$ \\
\hline \multirow[t]{2}{*}{$\triangle \mathrm{REER}$} & $-0.019^{* * *}$ & $-0.046^{* * *}$ & -0.0005 & -0.0007 \\
\hline & $(0.005)$ & $(0.006)$ & $(0.001)$ & $(0.0006)$ \\
\hline \multirow[t]{2}{*}{ Commodity price index } & -0.003 & $0.01^{* *}$ & $0.007^{* * *}$ & $0.009^{* * *}$ \\
\hline & $(0.004)$ & $(0.004)$ & $(0.002)$ & $(0.0004)$ \\
\hline \multirow[t]{2}{*}{ Net foreign assets (\% of GDP) } & 1.502 & $-8.069^{* * *}$ & $1.432^{* *}$ & $-2.192^{* * *}$ \\
\hline & $(1.612)$ & $(1.817)$ & $(0.582)$ & $(0.10)$ \\
\hline \multirow[t]{2}{*}{ Openness of trade } & $0.022^{*}$ & $0.096^{* * *}$ & $0.006^{* *}$ & $0.045^{* * *}$ \\
\hline & $(0.019)$ & $(0.02)$ & $(0.008)$ & $(0.002)$ \\
\hline \multirow[t]{2}{*}{ de jure capital openness } & -0.321 & -2.576 & -0.391 & $-1.558^{* *}$ \\
\hline & $(3.352)$ & $(2.443)$ & $(4.472)$ & $(0.313)$ \\
\hline \multirow[t]{2}{*}{ Exchange rate stability index } & $2.171^{*}$ & $-1.171^{* *}$ & $-1.177^{*}$ & $-1.767^{*}$ \\
\hline & $(1.810)$ & $(1.821)$ & $(1.672)$ & $(0.206)$ \\
\hline Sargan test ( $p$ value) & 0.181 & 0.174 & 0.183 & 0.212 \\
\hline Hansen $J$ test ( $p$ value) & 0.213 & 0.197 & 0.206 & 0.251 \\
\hline A-B test $A R(1)$ ( $p$ value) & 0.042 & 0.021 & 0.001 & 0.003 \\
\hline A-B test $A R(2)$ ( $p$ value) & 0.383 & 0.382 & 0.390 & 0.377 \\
\hline Observations & 837 & 992 & 1457 & 3286 \\
\hline Number of countries & 27 & 32 & 47 & 106 \\
\hline
\end{tabular}

Dependent variable is current account balance (\% of GDP)

Standard errors in parentheses

*** Significant at $1 \%$; ** significant at $5 \%$; * significant at $10 \%$

in all specifications, and the effect is quite similar, which means it has persistency as described earlier (Sect. 5.2).

Column 1 of Table 4 presents the result from specification (1) containing the standard variables posited by the literature and new determinants. It demonstrates the result for developed economies considering the relatively new determinant, i.e., commodity price, exchange rate stability and de jure capital openness along with the theoretically established determinants, e.g., real GDP growth rate, real effective exchange rate, net foreign assets and trade openness. Each coefficient has expected sign, and most of them are significantly different from zero. The coefficient of lagged dependent variable shows that the current account deficit in developed economies is persistent.

The real GDP growth rate $(-0.174)$ has a significant negative influence on current account balance. This implies that increasing real GDP growth will amplify developed country's higher income leading more consumption expenditure resulting negative impact on current account balance. This result is also confirmed by Glick and Rogoff (1995), Chinn and Prasad (2003), (Bussière et al. 2004) and Chinn and Ito (2007). Similarly, the real effective exchange rate is significantly negative, as expected, but is far smaller than unity $(-0.019)$. This finding is supported by the previous works (Obstfeld and Rogoff 1995a; Herrmann and Jochem 2005) which demonstrates that increase in 
Table 5 System dynamic panel estimation results (Blundell and Bond 1998 system GMM approach)

\begin{tabular}{lllll}
\hline & $\mathbf{( 1 )}$ & $\mathbf{( 2 )}$ & $\mathbf{( 3 )}$ & $\mathbf{( 4 )}$ \\
& Developed & Emerging & Developing & Full sample \\
\hline Lag CAB (\% of GDP) & $0.740^{* * *}$ & $0.407^{* * *}$ & $0.645^{* * *}$ & $0.414^{* * *}$ \\
& $(0.045)$ & $(0.003)$ & $(0.013)$ & $(0.001)$ \\
Real GDP growth rate & $-0.225^{* * *}$ & $0.819^{* * *}$ & $-0.049^{* * *}$ & $0.471^{* * *}$ \\
& $(0.018)$ & $(0.024)$ & $(0.016)$ & $(0.003)$ \\
$\Delta$ REER & $-0.016^{* * *}$ & $-0.103^{* * *}$ & $-0.003^{* *}$ & $-0.008^{* * *}$ \\
& $(0.006)$ & $(0.009)$ & $(0.001)$ & $(0.0009)$ \\
Commodity price index & -0.005 & $0.0139^{* * *}$ & $0.009^{* * *}$ & 0.0001 \\
& $(0.005)$ & $(0.004)$ & $(0.002)$ & $(0.0004)$ \\
Net foreign assets (\% of GDP) & 2.893 & -0.423 & $2.064^{* * *}$ & $-0.146^{* *}$ \\
& $(1.957)$ & $(0.538)$ & $(0.715)$ & $(0.064)$ \\
Openness of trade & $0.042^{* * *}$ & $0.036^{* * *}$ & 0.011 & $0.066^{* * *}$ \\
de jure capital openness & $(0.013)$ & $(0.011)$ & $(0.008)$ & $(0.002)$ \\
& -1.114 & 0.981 & -4.499 & $-0.856^{*}$ \\
Exchange rate stability index & $(3.749)$ & $(2.139)$ & $(4.094)$ & $(0.153)$ \\
Sargan test $(p$ value) & $1.517^{*}$ & $-2.079^{* *}$ & $-0.712^{*}$ & $-3.200^{* * *}$ \\
Hansen $J$ test $(p$ value) & $(1.084)$ & $(1.294)$ & $(1.369)$ & $(0.230)$ \\
Diff-in-Hansen test $(p$ value) & 0.231 & 0.185 & 0.217 & 0.280 \\
A-B test $A R(1)(p$ value) & 0.273 & 0.168 & 0.236 & 0.260 \\
A-B test $A R(2)(p$ value) & 0.183 & 0.151 & 0.179 & 0.231 \\
Observations & 0.056 & 0.021 & 0.000 & 0.014 \\
Number of countries & 0.483 & 0.458 & 0.478 & 0.479 \\
Depen & 837 & 992 & 1457 & 3286 \\
& 27 & 32 & 47 & 106 \\
\hline
\end{tabular}

Dependent variable is current account balance (\% of GDP)

Standard errors in parentheses

*** Significant at $1 \%$; ** significant at $5 \%$; * significant at $10 \%$

REER will decrease country's savings. Because, it will appreciate the domestic currency, thereby influencing to purchase more important goods from abroad. Therefore, much spending on consumption will result in lowering savings ratio, which leads to lessen current account balance.

Commodity price index $(-0.003)$ has exerted a negative influence on current account balance as well. Since, developed economies are largely manufacture exporter and commodity importer, so soaring of commodity price will increase the import value of commodity products which will widen the current account deficit. Although the coefficient is insignificant and very tiny in value, its right expected sign creates an insight to include this indicator. The net foreign assets plots show a positive relationship, which reveals that developed countries have relatively large stock of net foreign assets that will lead to large current account surplus. The coefficient estimated for trade openness impacts by 0.022. Alike, Chinn and Prasad (2003) and Chinn and Ito (2007) advocate the degree of openness to international trade could reflect tariff regime and other policy choice will have a positive effect on current account. Moreover, the positive impact of trade openness on the current account implies that economy with less trade restrictions and more 
exposure to international trade tends to be relatively more attractive to foreign capital. Thus, larger current account balance is associated with greater degree of trade openness.

The coefficient of the de jure capital openness captures negative impact $(-0.32)$. As it is measured based on binary dummy which reflects cross-border financial transaction restriction, i.e., multiple exchange rate, current account transaction and capital account transaction reported in IMF's AREAER (Chinn and Ito 2008). Accordingly, the coefficient implies that countries are more open for capital and financial transaction that would lead them a negative current account.

Exchange rate stability index in which value ranges from 0 (unstable) to 1 (stable) is measured by Aizenman et al. (2008). The estimator finds exchange rate stability effect of 2.17 with a $10 \%$ significance level on the current account balance, meaning that capital will inflow in relatively stable exchange rate regime. In support with Aizenman et al. (2008), this result also finds a positive link in terms of developed country's current account balance. Specification (2) discloses the determinants of current account imbalance for emerging countries. The sign of the determinants is counterintuitive with developed economies. Unlike developed economies, real GDP growth rate and commodity price index have shown positive impact at a $1 \%$ significant level. As long as emerging economies are more cautious about their financial policy against Western exuberance in consumption and residential investment, massive export earnings help to boost up the current account surplus (Miller et al. 2011). Hence, the higher real GDP growth is more likely to increase their savings with less growing consumption. So, the higher real GDP growth rate steers the path of current account surplus. One of the striking results carrying from commodity price is the strong positive relationship with current account. However, the statistically significant coefficient captures a little positive impact. In fact, it gives a new message for current account since, emerging countries are primarily commodity exporters, and thus increasing commodity price will rise their export opportunities to the overseas.

On the other hand, net foreign assets and exchange rate stability have a statistically significant negative impact. Net foreign asset refers to total foreign assets minus total foreign liabilities; hence, the negative coefficient weigh the countries having more foreign liabilities record positive income flows. Next emerging economies' exchange rate stability is measured by considering the USA as base country, and thus increasing exchange rate stability will not impact positively on emerging economies' current account because of volatile US exchange rate. This result is also validated by Aizenman et al. (2008) for emerging economies. Similarly, real effective exchange rate, trade openness and de jure capital openness reflect the same magnitude on the current account likewise developed economies.

The results for the developing economies are shown in specification (3). The real GDP growth rate shows the similar negative impact at $1 \%$ significance level which also matches with the findings of Chinn and Prasad (2003). The coefficients of real effective exchange, net foreign asset, de jure capital openness and exchange rate stability are also followed by negative impact. This reports that high net foreign asset increases the foreign flows, and as a result from an intertemporal approach it supports the theory. Similarly, the coefficient of the real effective exchange rate implies that increased REER will reduce the propensity to save and thus this causes a deficit current account balance. For 
exchange rate stability likewise emerging economies, it measures USA as a base country; therefore, volatility in exchange rate will lead negative impact even if developing economies' stable exchange rate. Nevertheless, the coefficient of commodity price enters positively in current account which supports with the findings in terms of developing countries. Like emerging economies, developing economies are also primarily commodity exporter; thus, high commodity price accumulates high foreign earnings from export, which helps to improve the current account balance.

Lastly, specification (4) shows the result of full sample countries taking into account the same determinants. The sign and value of coefficients are quite dissimilar in comparison with different groups of countries. The result compactly shows that real effective exchange rate, net foreign asset, de jure capital openness and exchange rate stability are similar with emerging and developing economies.

However, to test the validity of the result the null hypothesis of Sargan and Hansen $J$ tests are not rejected, which implies that the first difference instrumental variables are not correlated with error term. Hence, the instruments are valid for the estimation. Subsequently, the Arellano-Bond test supports that there is no serial correlation, which entails the null hypothesis is that the errors in the first difference regression exhibit no second-order serial correlation.

\subsubsection{System GMM estimation}

Table 5 gives the full results of system GMM estimation. This analysis conducts the same explanatory variable set as it used in difference GMM technique. In addition, to get rid of the possible biases and imprecision associated with the difference GMM estimator, system GMM estimator combines the regression in difference with regression in levels. Under this system, this paper instrumented the net foreign assets and exchange rate stability to overcome the potential endogeneity which generates consistent and efficient parameters. The Sargan, Hansen, diff-in-Hansen and Arellano-Bond tests satisfy the validity of the instruments in the system GMM estimator.

The specification (1) to (4) has shown the coefficients are very close to those it obtained from the difference GMM estimator. For instance, commodity price index, real GDP growth, real effective exchange rate and trade openness have almost same coefficient for developed, emerging, developing and full samples as reported in the difference GMM result (Table 5), while net foreign assets, de jure capital openness and exchange rate stability have comparatively large impact in the system dynamic panel GMM result reported in Table 5 [specification (1)-(4)]. The sign and value of coefficients are quite similar in comparison with other specifications, i.e., developed, emerging and developing. As noted earlier, these coefficients suggest that the exogenous change in the determinants implies a large change in current account balance. Subsequently, the positive lagged dependent variable suggests the existence of significant dynamic effect on the current account balance.

The specification tests indicate that all models are well specified in terms of endogeneity and instruments validity. The row for Sargan and Hansen $J$ tests ( $p$ value) reports that the null hypothesis of the over identifying restrictions is valid in all specifications. The $p$-value for diff-in-Hansen test suggests that additional moment conditions are valid for the system GMM model. Similarly, the Arellano-Bond test supports that there is no 
serial correlation, which entails the null hypothesis is that there are high first-order autocorrelation and no evidence for significant second-order serial correlation.

In summary, this paper gets the expected results which capture the some important determinants (commodity price, de jure and de facto capital openness and exchange rate stability) together with commonly used determinants in the literature such as net foreign asset, real effective exchange rate, trade openness and real GDP growth of current account balance. As difference GMM estimators are strongly downward biased, Blundell and Bond (1998) proposed system GMM estimators to mitigate this issue. Thus, in this research system GMM estimators show more consistent and unbiased results compared with the difference GMM. So, here it placed both results to show that how downward biased difference GMM estimators produce more inflated impact than system GMM estimator. Therefore, in this paper system GMM estimator shows the real impact which can be contributed to the theoretical and policy implication of global current account imbalance.

\section{Robustness}

This section examines the robustness and sign of the results using adding different variables. For robustness check here two additional variables (de facto capital openness and Asian crisis dummy) instead of de jure capital openness and net foreign assets are included. All robustness check specifications use the same dynamic panel GMM techniques (see Sect. 5.2). The results obtained (Tables 6, 7) are virtually identical to those reported in specification (1)-(4) (Tables 4, 5). Furthermore, when it included de facto capital openness and Asian crisis dummy, in both difference and system dynamic panel GMM estimates, this paper still finds a significant relationship between the exogenous components of the determinants of current account balance with the unchanged sign.

In Tables 6 and 7, this paper replaced the net foreign assent and de jure capital openness by Asian crisis dummy and de facto capital openness. By doing so, the effects of the contemporaneous determinants and lagged dependent variable are very similar for developed, emerging and developing economies group. Here, the de facto capital openness has negative effects similarly as de jure capital openness on current account in different country groups. Thus, the result confirms that there is no surprise change that obtained in the main specifications in Tables 4 and 5.

To sum up, all of global current account determinants (real GDP growth rate, net foreign assets, commodity price index, real effective exchange rate, trade openness, exchange rate stability and de facto capital openness) show the significant effect on current account balance. Besides, the specification tests (Sargan, Hansen $J$, diff-in-Hansen and Arellano-Bond tests) support the robustness check results. This implies that robustness results pass from endogeneity and serial correlation bias. Therefore, conclude that the estimated coefficients derived from the quantitative measures are robust.

\section{Conclusion}

The nature of current account imbalance, their importance and their potential path in the global economy have been taken a mainstream debate on the international macroeconomic outlook. This research examined the determinants of current account imbalance in global economy where, two econometric techniques to find the determinants 
Table 6 Robustness checks (difference dynamic panel estimation)

\begin{tabular}{lllll}
\hline & $\mathbf{( 1 )}$ & $\mathbf{( 2 )}$ & $\mathbf{( 3 )}$ & $\mathbf{( 4 )}$ \\
& Developed & Emerging & Developing & Full sample \\
\hline Lag CAB (\% of GDP) & $0.684^{* * *}$ & $0.384^{* * *}$ & $0.615^{* * *}$ & $0.404^{* * *}$ \\
Real GDP growth rate & $(0.039)$ & $(0.004)$ & $(0.031)$ & $(0.0009)$ \\
& $-0.156^{* * *}$ & $0.661^{* * *}$ & $-0.0389^{* * *}$ & $0.366^{* * *}$ \\
$\triangle$ REER & $(0.023)$ & $(0.035)$ & $(0.009)$ & $(0.002)$ \\
Commodity price index & $-0.0157^{* * *}$ & $-0.059^{* * *}$ & -0.0008 & $-0.003^{* * *}$ \\
& $(0.004)$ & $(0.003)$ & $(0.001)$ & $(0.0006)$ \\
Openness of trade & -0.003 & 0.0005 & $0.006^{* * *}$ & $0.002^{* * *}$ \\
de facto capital openness & $(0.004)$ & $(0.004)$ & $(0.001)$ & $(0.0004)$ \\
Exchange rate stability index & 0.007 & $0.164^{* * *}$ & 0.002 & $0.073^{* * *}$ \\
Asian crisis dummy & $(0.011)$ & $(0.038)$ & $(0.006)$ & $(0.001)$ \\
Sargan test $(p$ value) & -0.0002 & $-0.004^{* * *}$ & $-0.004^{* *}$ & $-0.007^{* *}$ \\
Hansen J test $(p$ value) & $(0.0004)$ & $(0.0003)$ & $(0.001)$ & $(0.0002)$ \\
A-B test $A R(1)(p$ value) & $6.611^{* *}$ & -0.418 & -0.035 & $-2.405^{* * *}$ \\
A-B test $A R(2)(p$ value) & $(3.073)$ & $(1.917)$ & $(1.196)$ & $(0.168)$ \\
Observations & 12.25 & $-22.37^{*}$ & - & 0.855 \\
Number of countries & $(7.649)$ & $(12.63)$ & - & $(1.114)$ \\
\hline Dep & 0.121 & 0.191 & 0.214 & 0.192 \\
& 0.172 & 0.178 & 0.227 & 0.219 \\
& 0.032 & 0.041 & 0.004 & 0.001 \\
& 0.483 & 0.482 & 0.490 & 0.477 \\
& 837 & 992 & 1457 & 3286 \\
& 27 & 32 & 47 & 106 \\
\hline
\end{tabular}

Dependent variable is current account balance (\% of GDP)

Standard errors in parentheses

*** Significant at $1 \%$, ${ }^{* *}$ significant at $5 \%$, ${ }^{*}$ significant at $10 \%$

empirically: first, difference GMM dynamic panel and, second, system GMM dynamic panel estimators. This study is specially designed to deal with the key problems of the past literature of the global current account imbalance, for instance omitted variable bias, endogeneity and simultaneity bias originating from unobserved country-specific effects. As a robustness check, this paper also used the same techniques with adjusted variables. The both results present the same story; the exogenous determinants have a strong impact on current account balance. In particular, current account balance has positive link with commodity price real GDP growth and trade openness in emerging economies, whereas negative link in developed economies. In contrast, it has a significant negative channel with net foreign assets, real effective exchange rate and exchange rate stability in terms of emerging economies and, on the other hand, a positive channel with these variables except real effective exchange rate. However, to overcome endogeneity, simultaneity and omitted variable bias the specification tests (Sargan, Hansen J, diff-in-Hansen and Arellano-Bond) support the estimated results.

Finally, this research reveals the implication of incorporating new determinants such as commodity price, exchange rate stability and de jure capital openness. Compacting this intuition, results support Chinn and Prasad (2003) and Chinn and ito (2007) analysis. Due to data limitation, however, this paper does not conduct the comprehensive 
Table 7 Robustness checks (system dynamic panel estimation)

\begin{tabular}{lllll}
\hline & $\mathbf{( 1 )}$ & $\mathbf{( 2 )}$ & $\mathbf{( 3 )}$ & $\mathbf{( 4 )}$ \\
& Developed & Emerging & Developing & Full sample \\
\hline Lag CAB (\% of GDP) & $0.798^{* * *}$ & $0.400^{* * *}$ & $0.639^{* * *}$ & $0.405^{* * *}$ \\
& $(0.031)$ & $(0.007)$ & $(0.028)$ & $(0.0006)$ \\
Real GDP growth rate & $-0.215^{* * *}$ & $0.798^{* * *}$ & $-0.028^{* *}$ & $0.458^{* * *}$ \\
& $(0.018)$ & $(0.033)$ & $(0.012)$ & $(0.004)$ \\
$\triangle$ REER & $-0.014^{* * *}$ & $-0.091^{* * *}$ & $-0.004^{* *}$ & $-0.008^{* * *}$ \\
Commodity price index & $(0.004)$ & $(0.011)$ & $(0.002)$ & $(0.001)$ \\
& -0.005 & $0.009^{* * *}$ & $0.007^{* * *}$ & $-0.004^{* * *}$ \\
Openness of trade & $(0.003)$ & $(0.003)$ & $(0.001)$ & $(0.0005)$ \\
de facto capital openness & -0.004 & $0.042^{* * *}$ & -0.003 & $0.084^{* * *}$ \\
Exchange rate stability index & $(0.025)$ & $(0.008)$ & $(0.005)$ & $(0.002)$ \\
Asian crisis dummy & 0.0001 & $-0.002^{* * *}$ & $-0.004^{* * *}$ & $-0.006^{* * *}$ \\
Sargan test $(p$ value) & $(0.0006)$ & $(0.0001)$ & $(0.001)$ & $(0.0001)$ \\
Hansen $J$ test $(p$ value) & 1.081 & $-4.948^{* *}$ & 0.304 & $-2.937^{* * *}$ \\
Diff-in-Hansen test $(p$ value) & $(1.683)$ & $(1.925)$ & $(1.034)$ & $(0.135)$ \\
A-B test $A R(1)(p$ value) & $10.54^{*}$ & $-2.253^{*}$ & - & 0.684 \\
A-B test $A R(2)(p$ value) & $(6.071)$ & $(18.74)$ & - & $(0.612)$ \\
Observations & 0.193 & 0.214 & 0.197 & 0.221 \\
Number of countries & 0.172 & 0.178 & 0.227 & 0.219 \\
\hline Depend & 0.138 & 0.163 & 0.211 & 0.194 \\
& 0.024 & 0.011 & 0.007 & 0.004 \\
& 0.583 & 0.582 & 0.590 & 0.577 \\
& 837 & 992 & 1457 & 3286 \\
& 27 & 32 & 47 & 106 \\
\hline
\end{tabular}

Dependent variable is current account balance (\% of GDP)

Standard errors in parentheses

*** Significant at $1 \%$; ${ }^{* *}$ significant at $5 \%$; ${ }^{*}$ significant at $10 \%$

evaluation of the net foreign asset and commodity price valuation, capital controls and international risk management, which is also very important to measure the global current account imbalance. Future work should considerably be widen and intense to understand the determinants in this context.

Acknowledgements

The author thanks anonymous referee.

Competing interests

The author declares that he has no competing interests.

\section{Appendix}

See Tables 8 and 9. 
Table 8 List of countries and sample years

\begin{tabular}{|c|c|c|c|}
\hline \multicolumn{3}{|l|}{ Countries } & \multirow[t]{2}{*}{ Sample years } \\
\hline Developed countries (27 & & & \\
\hline Australia & Hungary & New Zealand & $1980-2011$ \\
\hline Austria & Iceland & Norway & $1980-2011$ \\
\hline Canada & Ireland & Portugal & $1980-2011$ \\
\hline Cyprus & Israel & Spain & $1980-2011$ \\
\hline Denmark & Italy & Sweden & $1980-2011$ \\
\hline Finland & Japan & Switzerland & $1980-2011$ \\
\hline France & Korea, Rep. & Trinidad and Tobago & $1980-2011$ \\
\hline Germany & Malta & UK & $1980-2011$ \\
\hline Greece & Netherlands & USA & $1980-2011$ \\
\hline \multicolumn{4}{|c|}{ Emerging countries (32 countries) } \\
\hline Argentina & Jordan & Poland & $1980-2011$ \\
\hline Bahrain & Kuwait & Saudi Arabia & 1980-2011 \\
\hline Bangladesh & Malaysia & Singapore & $1980-2011$ \\
\hline Botswana & Mauritius & South Africa & $1980-2011$ \\
\hline Brazil & Mexico & Sri Lanka & $1980-2011$ \\
\hline Chile & Morocco & Sudan & $1980-2011$ \\
\hline China & Nigeria & Thailand & $1980-2011$ \\
\hline Colombia & Oman & Turkey & $1980-2011$ \\
\hline Egypt & Pakistan & Tunisia & $1980-2011$ \\
\hline India & Peru & Venezuela & 1980-2011 \\
\hline Indonesia & Philippines & & \\
\hline \multicolumn{4}{|c|}{ Developing countries (47 countries) } \\
\hline Angola & Ethiopia & Nepal & 1980-2011 \\
\hline Antigua and Barbuda & Fiji & Nicaragua & 1980-2011 \\
\hline Belize & Gambia, The & Niger & 1980-2011 \\
\hline Benin & Ghana & Panama & 1980-2011 \\
\hline Bolivia & Grenada & Papua New Guinea & 1980-2011 \\
\hline Burkina Faso & Guinea-Bissau & Paraguay & 1980-2011 \\
\hline Burundi & Guatemala & Rwanda & 1980-2011 \\
\hline Cameroon & Guyana & Senegal & 1980-2011 \\
\hline Cape Verde & Honduras & Sierra Leone & 1980-2011 \\
\hline Congo, Rep. & Jamaica & Syria & 1980-2011 \\
\hline Costa Rica & Kenya & Swaziland & $1980-2011$ \\
\hline Cote d'Ivoire & Lesotho & Togo & $1980-2011$ \\
\hline Dominica & Madagascar & Uganda & 1980-2011 \\
\hline Dominican Republic & Malawi & Uruguay & 1980-2011 \\
\hline Ecuador & Mali & Zambia & 1980-2011 \\
\hline El Salvador & Mozambique & & 1980-2011 \\
\hline
\end{tabular}


Table 9 Description of the variables and sources

\begin{tabular}{|c|c|c|}
\hline Variable & Descriptions & Sources \\
\hline $\begin{array}{l}\text { Current account balance } \\
\text { (\% of GDP) }\end{array}$ & $\begin{array}{l}\text { Current account balance is the sum of net exports of goods, } \\
\text { services, net income and net current transfers as a share of } \\
\text { gross domestic product }\end{array}$ & $\begin{array}{l}\text { IMF-BOPS, IMF-WEO } \\
\text { and WDI and own } \\
\text { calculation }\end{array}$ \\
\hline $\begin{array}{l}\text { Real GDP growth rate } \\
\text { (annual \%) }\end{array}$ & $\begin{array}{l}\text { Real GDP growth rate is a measure of the rate of change in } \\
\text { GDP from one year to another }\end{array}$ & UNCTAD \\
\hline $\begin{array}{l}\Delta \text { Real effec- } \\
\text { tive exchange } \\
\text { rate (annual \%) } \\
(2005=100)\end{array}$ & $\begin{array}{l}\text { Real effective exchange rate is the nominal effective exchange } \\
\text { rate (a measure of the value of a currency against a } \\
\text { weighted average of several foreign currencies) divided by a } \\
\text { price deflator or index of costs }\end{array}$ & $\begin{array}{l}\text { IMF-IFS, Z-D, BIS and } \\
\text { own calculation }\end{array}$ \\
\hline Commodity price index & $\begin{array}{l}\text { Commodity price index considered as an interaction dummy } \\
\text { variable that takes the average value of the prime exporting } \\
\text { commodities of the respecting commodities exporting } \\
\text { countries and } 0 \text { for the manufacturing countries }\end{array}$ & $\begin{array}{l}\text { UNCTAD and Own } \\
\text { calculation }\end{array}$ \\
\hline Net foreign assets/GDP & $\begin{array}{l}\text { Net foreign assets measured by total assets minus total } \\
\text { liabilities over GDP, where total assets are the sum of foreign } \\
\text { direct investment assets, portfolio equity assets, debt assets, } \\
\text { financial derivatives assets and foreign exchange reserves } \\
\text { excluding gold and total liabilities are the sum of foreign } \\
\text { direct investment liabilities, portfolio equity liabilities, debt } \\
\text { liabilities, financial derivatives liabilities }\end{array}$ & $\begin{array}{l}\text { L-M-F, IFS and own } \\
\text { calculation }\end{array}$ \\
\hline Trade openness & $\begin{array}{l}\text { Trade openness is the sum of exports and imports measured } \\
\text { as a share of gross domestic product }\end{array}$ & WDI \\
\hline $\begin{array}{l}\text { de jure capital openness } \\
\text { (Chinn-Ito index) }\end{array}$ & $\begin{array}{l}\text { Dejure capital openness measured by Chinn and Ito (2008) } \\
\text { based on information regarding restrictions in the IMF's } \\
\text { Annual Report on Exchange Arrangements and Exchange } \\
\text { Restrictions (AREAER). The Chinn-Ito index is normalized } \\
\text { between } 0 \text { and } 1 \text {. Higher values of this index indicate that a } \\
\text { country is more open to cross-border capital transactions }\end{array}$ & $C-1$ \\
\hline $\begin{array}{l}\text { De facto capital open- } \\
\text { ness }\end{array}$ & $\begin{array}{l}\text { De facto capital openness measured by the sum of total } \\
\text { foreign assets and total foreign liabilities over gross domestic } \\
\text { product multiplied by } 100\end{array}$ & $\begin{array}{l}\text { L-M-F, IFS and own } \\
\text { calculation }\end{array}$ \\
\hline $\begin{array}{l}\text { Exchange rate stability } \\
\text { index }\end{array}$ & $\begin{array}{l}\text { To measure exchange rate stability (Aizenman et al. 2010), } \\
\text { consider that annual standard deviations of the monthly } \\
\text { exchange rate between the home country and the base } \\
\text { country are calculated and included in the following formula } \\
\text { to normalize the index between } 0 \text { and } 1: \\
\text { ERS }=0.01 / 0.01+\text { stdev( }(\text { (log(exchange rate))) } \\
\text { Higher values of this index indicate more stable movement of } \\
\text { the exchange rate against the currency of the base country }\end{array}$ & $A-C-1$ \\
\hline Crisis dummy & $\begin{array}{l}\text { Crisis dummy considered as a dummy variable that takes the } \\
\text { value of } 1 \text { during the years of banking, currency and Asian } \\
\text { crisis happen and } 0 \text { otherwise }\end{array}$ & $L-V$ \\
\hline Asian crisis dummy & $\begin{array}{l}\text { Asian crisis dummy considered as a dummy variable that takes } \\
\text { the value of } 1 \text { during the years of Asian crisis happen and } 0 \\
\text { otherwise }\end{array}$ & $L-V$ \\
\hline
\end{tabular}

IMF-BOPS is 2012 version of International Monetary Fund-Balance of Payment Statistics database, IMF-WEO is 2012 version of IMF World Economic Outlook database, IMF-IFS is 2012 version of IMF International Financial Statistics database, WD/ is 2012 version of World Bank Development Indicators database, UNCTAD is 2012 version of United Nations Conference for Trade and Development, BIS is 2011 version of Bank of International Settlements, $L-M-F$ is update and extended version of database constructed by Lane and Milesi-Ferretti (2008), C-l is updated and extended version of database constructed by Chinn and Ito (2012), Pen World Table 7.1 is 2012 updated version of database constructed by University of Pennsylvania, $L-V$ is updated and extended version of dataset constructed by Laeven and Valencia (2012), A-C-/ is updated and extended version of dataset constructed by Aizenman, Chinn and Ito (2012) and Z-D is 2012 version of dataset constructed by Darvas (2012) 
Received: 13 January 2015 Revised: 22 August 2015 Accepted: 8 March 2016

Published online: 18 March 2016

\section{References}

Abiad A, Detragiache E, Tressel T (2009) A new database of financial reforms. IMF Staff Pap 57(2):281-302

Aguiar MA, Amador M (2011) Fiscal policy in debt constrained economies. National Bureau of Economic Research, No. w17457

Aizenman J (2006) International reserves management and the current account. National Bureau of Economic Research, No. w12734

Aizenman J, Chinn MD, Ito H (2008) Assessing the emerging global financial architecture: measuring the trilemma's configurations over time. National Bureau of Economic Research, No. w14533

Aizenman J, Chinn MD, Ito H (2010) The emerging global financial architecture: tracing and evaluating new patterns of the trilemma configuration. J Int Money Finance 29(4):615-641

Aizenman J, Chinn M, Ito H (2012) The trilemma indices. http://web.pdx.edu/ ito/trilemma_indexes.htm. Accessed $25 / 07 / 2012$

Akerlof GA, Shiller RJ (2010) Animal spirits: How human psychology drives the economy, and why it matters for global capitalism. Princeton University Press, New Jersey

Alfaro L, Kalemli-Ozcan S, Volosovych V (2008) Why doesn't capital flow from rich to poor countries? An empirical investigation. Rev Econ Stat 14:597-605

Arellano M, Bond S (1991) Some tests of specification for panel data: Monte Carlo evidence and an application to employment equations. Rev Econ Stud 58(2):277

Arellano M, Bover O (1995) Another look at the instrumental variable estimation of error-components models. J Econom 68(1):29-51

Baltagi BH (2008) Forecasting with panel data. J Forecast 27(2):153-173

Bergin PR (2006) How well can the new open economy macroeconomics explain the exchange rate and current account? J Int Money Finance 25(5):675-701

Bernanke B (2005) The global saving glut and the US current account deficit. Remarks at the Sandridge Lecture, Virginia Association of Economics, Richmond, Virginia 10

Blanchard O, Giavazzi F, Sa F (2005) The US current account and the dollar. National Bureau of Economic Research, No. W11137

Blundell R, Bond S (1998) Initial conditions and moment restrictions in dynamic panel data models. J Econom $87(1): 115-143$

Blundell R, Bond S (2000) GMM estimation with persistent panel data: an application to production functions. Econom Rev 19(3):321-340

Blundell R, Griffith R, Windmeijer F (2002) Individual effects and dynamics in count data models. J Econom 108(1):113-131

Bond SR, Hoeffler A, Temple J (2001) GMM estimation of empirical growth models, vol 3048. Centre for Economic Policy Research, London

Bracke T, Bussière M, Fidora M, Straub R (2010) A framework for assessing global imbalances. World Econ 33(9):11401174. doi:10.1111/j.1467-9701.2010.01266.x

Buera FJ, Shin Y (2009) Productivity growth and capital flows: The dynamics of reforms. National Bureau of Economic Research, No. w15268

Bussière M, Fratzscher M, Müller G (2004) Current account dynamics in OECD and EU acceding countries-an intertemporal approach. European Central Bank, No. 311

Caballero RJ, Farhi E, Gourinchas PO (2008) An equilibrium model of "global imbalances" and low interest rates. Am Econ Rev 98(1):358-393. doi:10.1257/aer.98.1.358

Calderon C, Chong A, Loayza N (2002) Determinants of current account deficits in developing countries. Contrib Macroecon 2(1):1-31

Calvo GA, Leiderman L, Reinhart CM (1993) Capital inflows and real exchange rate appreciation in Latin America: the role of external factors. Staff Pap Int Monet Fund 40(1):108-151

Carroll CD, Jeanne O (2009) A tractable model of precautionary reserves, net foreign assets, or sovereign wealth funds. National Bureau of Economic Research, No. w15228

Cheung C, Furceri D, Rusticelli E (2013) Structural and cyclical factors behind current account balances. Rev Int Econ 21(5):923-44

Chinn MD, Ito H (2007) Current account balances, financial development and institutions: assaying the world "saving glut". J Int Money Finance 26(4):546-569

Chinn MD, Ito H (2008) Global current account imbalances: American fiscal policy versus East Asian savings. Rev Int Econ 16(3):479-498

Chinn M, Ito H (2012) The Chinn-Ito index-a de jure measure of financial openness. http://web.pdx.edu/ ito/ChinnIto website.htm. Accessed 15 July 2012

Chinn MD, Prasad ES (2003) Medium-term determinants of current accounts in industrial and developing countries: an empirical exploration. J Int Econ 59:47-76

Chinn MD, Eichengreen B, Ito H (2014) A forensic analysis of global imbalances. Oxf Econ Pap 66(2):465-90

Clarida R (2005) Japan, China, and the US Current account deficit. Cato J 25(1):111-114

Clower E, Ito H (2011) The persistence and determinants of current account balances: the implications for global rebalancing. Santa Cruz Institute for International Economics, No. 11-09

Corbo V, Hernandez L (1996) Macroeconomic adjustment to capital inflows: lessons from recent Latin American and East Asian experience. World Bank Res Obs 11(1):61-85 
Darvas Z (2012) Real effective exchange rates for 178 countries: a new database. http://bruegel.org/publications/datasets/. Accessed 12 June 2012

De Mello L, Padoan PC, Rousová L (2012) Are global imbalances sustainable? Shedding further light on the causes of current account reversals. Rev Int Econ 20(3):489-516

De Mello L, Padoan PC, Rousová L (2011) The growth effect of current-account reversals. OECD Economics Department Working Papers, No. 871

Debelle G, Faruqee H (1996) What determines the current account? A cross-sectional and panel approach. IMF Working Paper 96/78

Debelle G, Galati G (2007) Current account adjustment and capital flows. Rev Int Econ 15(5):989-1013

Edwards S (1996) Why are the Latin America's savings rate too low? An international comparative analysis. J Dev Econ 51(1):389-418

Eichengreen B (2006) Global imbalances: the new economy, the dark matter, the savvy investor, and the standard analysis. J Policy Model 28(6):645-652

Fernandez-Arias E, Montiel PJ (1996) The surge in capital inflows to developing countries: an analytical overview. World Bank Econ Rev 10(1):51-77

Freund C, Warnock F (2007) Current account deficits in industrial countries: the bigger they are, the harder they fall? G7 current account imbalances: sustainability and adjustment. University of Chicago Press, Chicago, pp 133-168

Glick R, Rogoff K (1995) Global versus country-specific productivity shocks and the current account. J Monet Econ 35(1):159-192

Gourinchas PO, Jeanne O (2013) Capital flows to developing countries: the allocation puzzle. Rev of Econ Stu 80(4):1484-515

Gourinchas PO, Rey H (2007) From world banker to world venture capitalist: US external adjustment and the exorbitant privilege. G7 current account imbalances: sustainability and adjustment. University of Chicago Press, Chicago, pp $11-66$

Gruber JW, Kamin SB (2007) Explaining the global pattern of current account imbalances. J Int Money Finance 26(4):500-522

Herrmann S, Jochem A (2005) Determinants of current account developments in the central and east European EU member states-consequences for the enlargement of the euro area. Discussion Paper Series 1: Economic Studies

Holtz-Eakin D, Newey W, Rosen HS (1988) Estimating vector autoregressions with panel data. Econometrica J Econom Soc 1371-1395

Im KS, Pesaran MH, Shin Y (2003) Testing for unit roots in heterogeneous panels. J Econom 115(1):53-74

Ito H, Chinn M (2007) East Asia and global imbalances: saving, investment, and financial development. National Bureau of Economic Research, No. w13364

Johnson S, Kwak J (2011) 13 bankers: the wall street takeover and the next financial meltdown. Vintage Books, New York Ju J, Wei SJ (2006) A solution to two paradoxes of international capital flows. Int Monet Fund, No. WP/06/178

Laeven L, Valencia F (2012) The use of blanket guarantees in banking crises. J Int Money Finance 31 (5):1220-1248

Lane PR, Milesi-Ferretti GM (2008) International investment patterns. Rev Econ Stat 90(3):538-549

Lee MJ, Ostry MJD, Prati MA, Ricci MLA, Milesi-Ferretti MGM (2008) Exchange rate assessments: CGER methodologies. Int Monet Fund, No 261

Levin A, Lin CF, James Chu CS (2002) Unit root tests in panel data: asymptotic and finite-sample properties. J Econom 108(1):1-24

Lucas RE (1990) Why doesn't capital flow from rich to poor countries? Am Econ Rev 80(2):92-96

Mendoza EG, Quadrini V, Rios-Rull JV (2009) Financial integration, financial deepness and global imbalances. J Polit Econ 117(3):371-416

Milbourne R, Otto G (1992) Consumption smoothing and the current account. Aust Econ Pap 31(59):369-384

Milesi-Ferrett GM, Razin A (1996) Sustainability of persistent current account deficits. National Bureau of Economic Research, No. 5467

Milesi-Ferretti GM, Razin A (1998a) Sharp reductions in current account deficits an empirical analysis. Eur Econ Rev 42(3-5):897-908

Milesi-Ferretti GM, Razin A (1998) Current account reversals and currency crises, Empirical Regularities. National Bureau of Economic Research, No. w6620

Miller M, Santos Monteiro P, Zhang L (2011) Eastern caution, western exuberance and global imbalances. J Glob Dev 2(1): $1-40$

Obstfeld M, Rogoff K (1984) Exchange rate dynamics with sluggish prices under alternative price-adjustment rules. Int Econ Rev 25(1):159-174

Obstfeld M, Rogoff K (1995a) The Mirage of fixed exchange rates. J Econ Per 9(4):73-96

Obstfeld M, Rogoff K (1995b) Exchange rate dynamics redux. J Polit Econ 103(3):624-660

Obstfeld M, Rogoff KS (2005) Global current account imbalances and exchange rate adjustments. Brook Pap Econ Act 1:67-123

Obstfeld M, Rogoff K (2009) Global imbalances and the financial crisis: products of common causes. Paper presented at the Federal Reserve Bank of San Francisco Asia Economic Policy Conference, Santa Barbara, CA, October 18-20, 2009

Otto G, Voss GM (1995) Consumption, external assets and the real interest rate. J Macroecon 17(3):471-494

Prasad ES, Rajan RG, Subramanian A (2007) Foreign capital and economic growth. National Bureau of Economic Research, No. W13619

PWT (2012) Penn world table. http://pwt.econ.upenn.edu/php_site/pwt index.php. Accessed 25 July 2012

Raybaudi M, Sola M, Spagnolo F (2004) Red signals: current account deficits and sustainability. Econ Lett 84(2):217-223

Reinhart CM, Rogoff KS (2008) Is the 2007 US Sub-prime financial crisis so different? an international historical comparison. Am Econ Rev 98(2):339-344. doi:10.1257/aer.98.2.339

Sachs JD (1981) The current account in the eacroeconomic adjustment process. National Bureau of Economic Research, Cambridge 
Sheffrin SM, Woo WT (1990) Testing an optimizing model of the current account via the consumption function. J Int Money Finance 9(2):220-233

Stiglitz JE (2010) Interpreting the causes of the great recession of 2008. Financial system and macroeconomic resilience: revisited. Bank for International Settlements, Basel

Taylor AM (2002) A century of current account dynamics. J Int Money Finance 21 (6):725-748

Trehan B, Walsh CE (1991) Testing intertemporal budget constraints: theory and applications to US federal budget and current account deficits. J Money Credit Bank 23(2):206-223

Submit your manuscript to a SpringerOpen ${ }^{\circ}$ journal and benefit from:

- Convenient online submission

- Rigorous peer review

- Immediate publication on acceptance

- Open access: articles freely available online

- High visibility within the field

- Retaining the copyright to your article

Submit your next manuscript at $\boldsymbol{\nabla}$ springeropen.com 